\title{
Theories of the "Savage": \\ The Material Varek (Seagrass) \\ As a Bearer of Meaning in Psychiatry around 1900
}

Katrin Luchsinger

On November 24, 1913, the patient Lisette H. (1857-1924) made a women's hat out of seagrass in the Rheinau psychiatric hospital in the canton of Zurich, where she

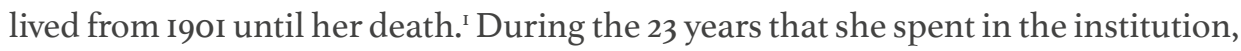
Lisette $\mathrm{H}$. made several objects out of this material, seven of which have survived (an eighth object is made of cotton waste). ${ }^{2}$ Seagrass was known as Varek and was used to stuff mattresses. In particular, the so-called "floor beds" in the isolation cells of psychiatric institutions were filled with Varek. ${ }^{3}$ At the Rheinau psychiatric hospital, Varek was used since 1897 because, unlike straw and horsehair, which were both also used, it was washable. ${ }^{4}$ Since the grass curls up as it dries, it had to be gently fluffed after being washed. Horsehair, which is not washed but only shaken out, is then fluffed in the same way, as shown in figure I. 


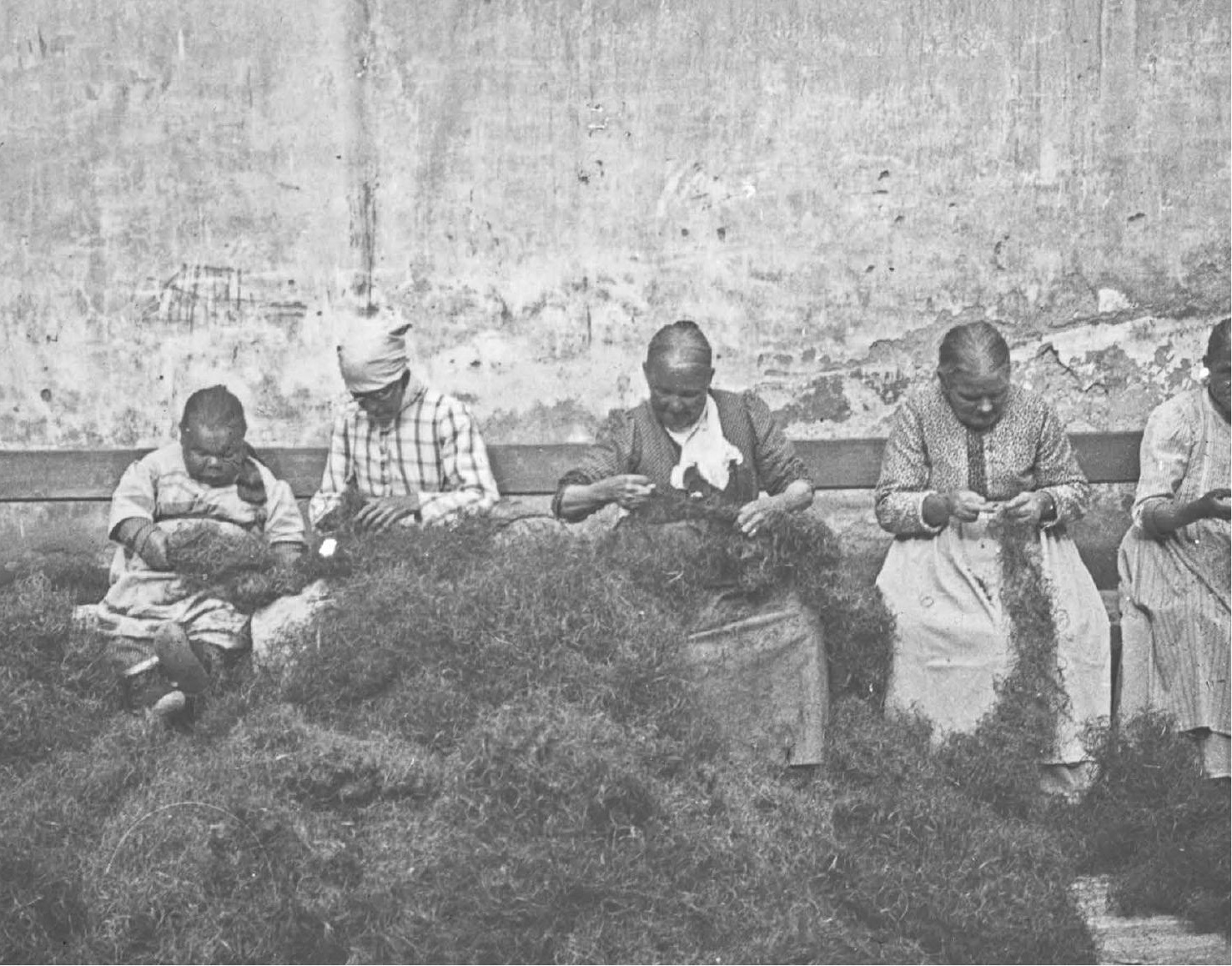

Seagrass (Zostera) grows in the sea near the coast at a depth of up to I5 meters. Narrow bands unfurl from the round stalks and can grow up to one meter long. They are common along the coasts of the Northern Hemisphere, Ireland, England, Scandinavia, and on the coasts of the North Sea and the Baltic Sea. In the winter, the dead seagrass is left behind in heaps on the beaches. In Denmark it was once used to cover roofs, and around 1900 it was exported as a material for filling mattresses, because it does not rot like straw when it becomes wet. At bathing beaches seagrass was and continues to be collected in the spring to keep the beach clean, after which it is either disposed of or converted into biogas. Some companies sell it as insulation material. Pillows with seagrass filling are available, and summer hats are woven out of it. The dried blades of grass (only the flat parts, not the stalks) are about two to eight millimeters wide, curly, and (due to the processing) only about 20 centimeters long, often shorter. The material smells earthy. Currently manufacturers recommend washing the filling from time to time in a washing machine. The grass curls up and then has to be spread out to dry and gently fluffed before being put back in the casing. 
In psychiatric hospitals around I900, "fluffing Varek" is mentioned as one of the jobs that was assigned to the patients (this job was reserved for women) in the "disturbed" wards for the most seriously ill, the least self-sufficient patients, or women who refused to comply with the nurses' or doctors' instructions, as will be discussed below. The material is very common and is not often mentioned in psychiatric writings. However, some photos show horsehair being gently fluffed, and seagrass must have been treated in a similar way. In these pictures, the horsehair lies in piles on the ground, from which one can conclude that, in accordance with its purpose, it was available in large quantities. In contrast, only limited amounts of wool or yarn were given to patients, which is why some female patients, and occasionally also male patients, used seagrass for other purposes, such as needlework, shoes, or jewelry, just as many other materials were used for new, sometimes artistic purposes for want of more suitable materials (Fahrni 2008). ${ }^{5}$

This study focuses on the use and importance of seagrass in Swiss psychiatry in the 2oth century. The seven works made of seagrass - a purse, a women's hat, two pairs of fine stockings, and a decorative doily ${ }^{6}$ - which survived from Lisette $\mathrm{H}$. will be a special focus of attention because their uniquely high quality demonstrates Lisette H.'s unbelievable skill in handicrafts. According to entries in her medical record, Lisette H. also made many other handicrafts from the material, which have been lost. ${ }^{7}$ Thematically the group of her works that survived concentrates on one major concern: the handbag, women's hat, baby's jacket, stockings, and decorative doily can stand for the housewife's work and belongings. Lisette $H$. was such a housewife before entering the psychiatric hospital. Based on these works by Lisette H., I will examine where and in what context patients came into contact with the material and what significance it had in the context of living and treatment at mental hospitals. Based on photos that depict the various uses of seagrass, the purpose for taking the photo and the context in which it might have been published will be investigated. Furthermore, I will consider the question of what purposes, besides stuffing mattresses, patients used Varek for due to a lack of more adequate materials. Medical record entries and photos documenting and commenting on such uses represent a kind of rudimentary "reception history" of the objects in the institution. ${ }^{8}$ The fact that objects made of seagrass were mentioned and commented on at all in patient files and textbooks is due to the fact that the discrepancy between the material and the object in its usual, familiar form was so great that it challenged the psychiatrist to interpret it in the context of mental illness. In order to be able to better reconstruct the conditions for the creation of her work, Lisette H.'s medical record will be used as an example for the argumentation in the following section. 


\section{Biographical References, Life in the Asylum, and Descriptions of Works}

Only two documents offer information about her biography, treatment, and the living and working conditions at the Rheinau psychiatric hospital: Lisette H.'s medical history and the "Registration of the patient Lisette H.-K., born on December I9, I857, for the Rheinau psychiatric hospital" from September 4, I90I. This document was written by the psychiatrist Eugen Bleuler (I857-I939), director of the Burghölzli university psychiatric clinic in Zurich from I898 to 1929. This institution was well known even outside of Switzerland. In I90 Bleuler decided to transfer the patient from Burghölzli, where she had been staying for eight years, since April 2I, I893, to the Rheinau psychiatric hospital for the incurably mentally ill. ${ }^{9}$ Bleuler begins his report: "The patient has a great hereditary burden," despite the fact that the following enumeration of relatives who supposedly had a hereditary disease by no means suggests as much. Lisette H.'s father was healthy, and her mother was supposedly melancholic. However, she did not die of this condition, but of tuberculosis. An uncle, Bleuler explains, "drowned in old age after he had no means of subsistence." It can be concluded that poverty and disease were present in Lisette H.'s family. In his registration letter, Eugen Bleuler emphasized or constructed the hereditary nature of her disease possibly with a view to her transfer from the university clinic to the psychiatric hospital, which was deemed to be unavoidable when the medical board pronounced the judgment of "incurability." A hereditary disease represented the strongest argument for this. At the age of 26, Lisette K. married the master weaver Heinrich H. She gave birth to five children, one of which was stillborn, and one of which died of meningitis as an infant. The other children were healthy.

"Patient used to be healthy, intelligent ... ; the marriage was happy, without worries," Bleuler writes in his report. Lisette H. worked as a housewife. In March I893 there was a "fire nearby," which might have been the trigger for a state of deep confusion. Bleuler now notes, in contradiction to his statement above, that she "did not really work before." Lisette H. was sent to the Catholic Mönchhof hospital in Kilchberg near Zurich, where she stayed for about a month. ${ }^{\text {Io }}$ From there she was transferred to the Burghölzli psychiatric clinic in Zurich on April 2I, I893. She "had to be kept in disturbed wards" in a cell, bath, or observation room and at times had to wear "gloves," the psychiatrist writes. The prolonged bath, the observation room, and the (fingerless) gloves can be described as compulsory measures (Meier et al. 2007: 3I-43), which in the case of Lisette $H$. were motivated by the fact that she could not adjust to the procedures in the wards and did harm to herself. ${ }^{\text {II }}$ 
For instance, she tore her clothes, which is why she had to wear "cell clothes," ${ }^{12}$ and ripped out her hair; she was anxious and agitated. "Now she is working on fluffing wool and horsehair, and often adorns herself with garlands of such material," Bleuler concludes his registration letter. On October 28, I90I, she arrived at the Rheinau psychiatric hospital with a "mass transport" (Gehry I932: I6) from Burghölzli, and she was taken to the newly opened facilities called "Neu-Rheinau." 's She died of tuberculosis there at the age of 67. Until 1906 there is a short entry in her medical history about every six weeks. Lisette H. was always assigned to "disturbed" wards, which were designated with the letter L at Neu-Rheinau: LI to L3. ${ }^{\text {I4 }}$ This suggests that she was unable to adjust to daily work with less monotonous (but more tiring) jobs than simply "fluffing Varek" or knitting, as was usual in the other wards. Since she "could not tolerate treatment in bed in the observation room" together with seven other patients, she was often in the "cell" and during the day "with the others." ${ }^{5}$ She knitted and "sits quietly at the table and fluffs Varek." ${ }^{16}$ On May 22, 1902, she "knitted a stocking out of split and knotted Varek, well-proportioned in form, using only a match" (fig. 2). ${ }^{17}$

The two stockings pictured here were in an envelope with the inscription "Varek stocking by Mrs. H. knitted with match. 3.5.1902." ${ }^{18}$ The stocking mentioned in the medical record is probably one of the two stockings shown here. These, as well as the remark "knitted with a match," raise many questions. They are knee-length socks, 40 and 34 centimeters long. The foot corresponds approximately to the shoe size 35. One of the stockings has a crocheted edging made of cotton thread. Both are knitted with plain stitches (not crocheted), for which five needles (or, to at least fulfil the principle of knitting, two needles) would be necessary. However, these two stockings are round, knitted without a seam. The mention of "a" match remains inexplicable. As was mentioned, Lisette H. split the seagrass lengthwise into pieces one to two millimeters wide, and in some cases even thread-like bands, each of which was only about 20 centimeters long. Some protruding ends of threads can be seen. The leg section of the stocking has different colors, with lighter and darker stripes, corresponding to the natural material (fig. 3). The instep clearly shows that the stitches were gathered and the heel was knitted. In the front Lisette H. shaped 


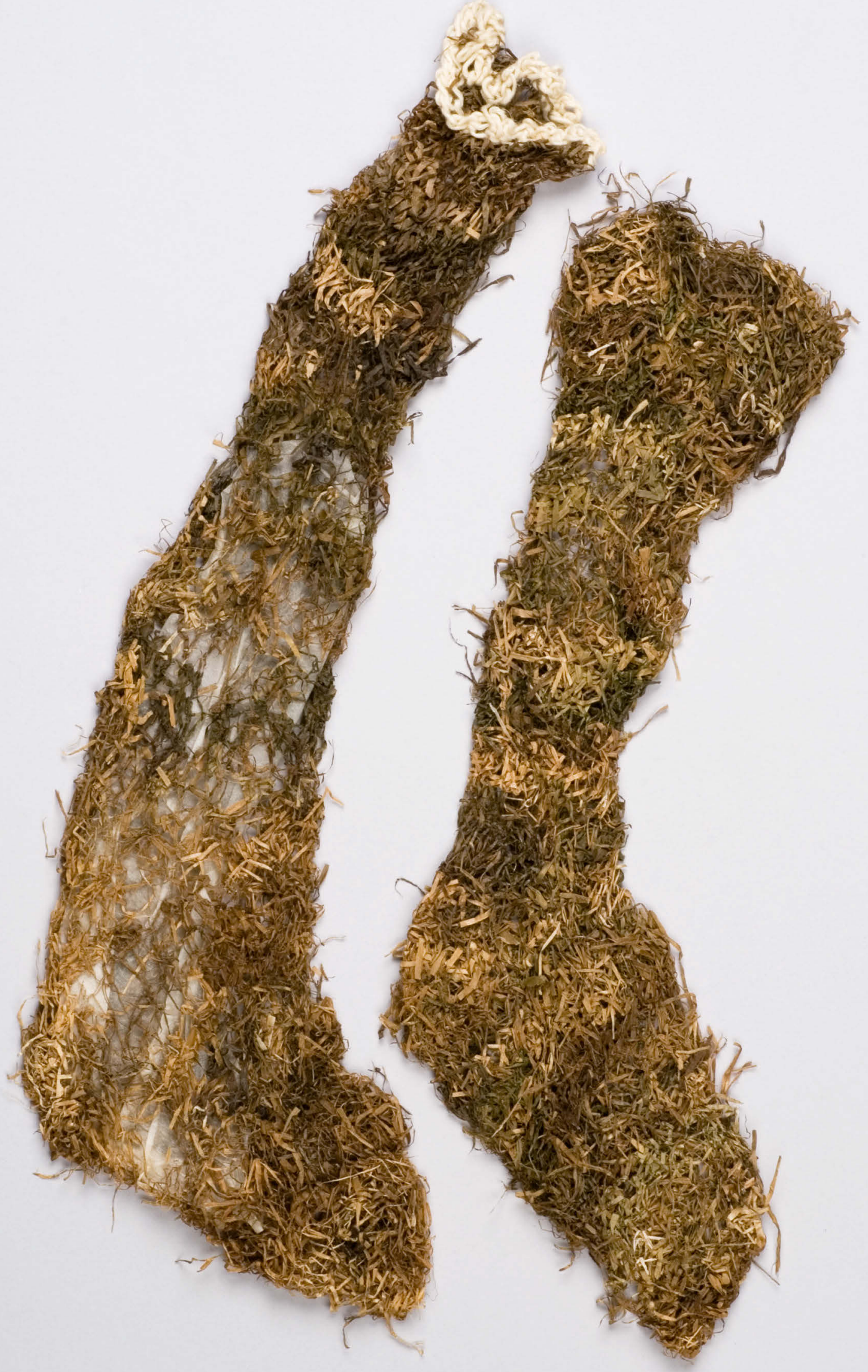



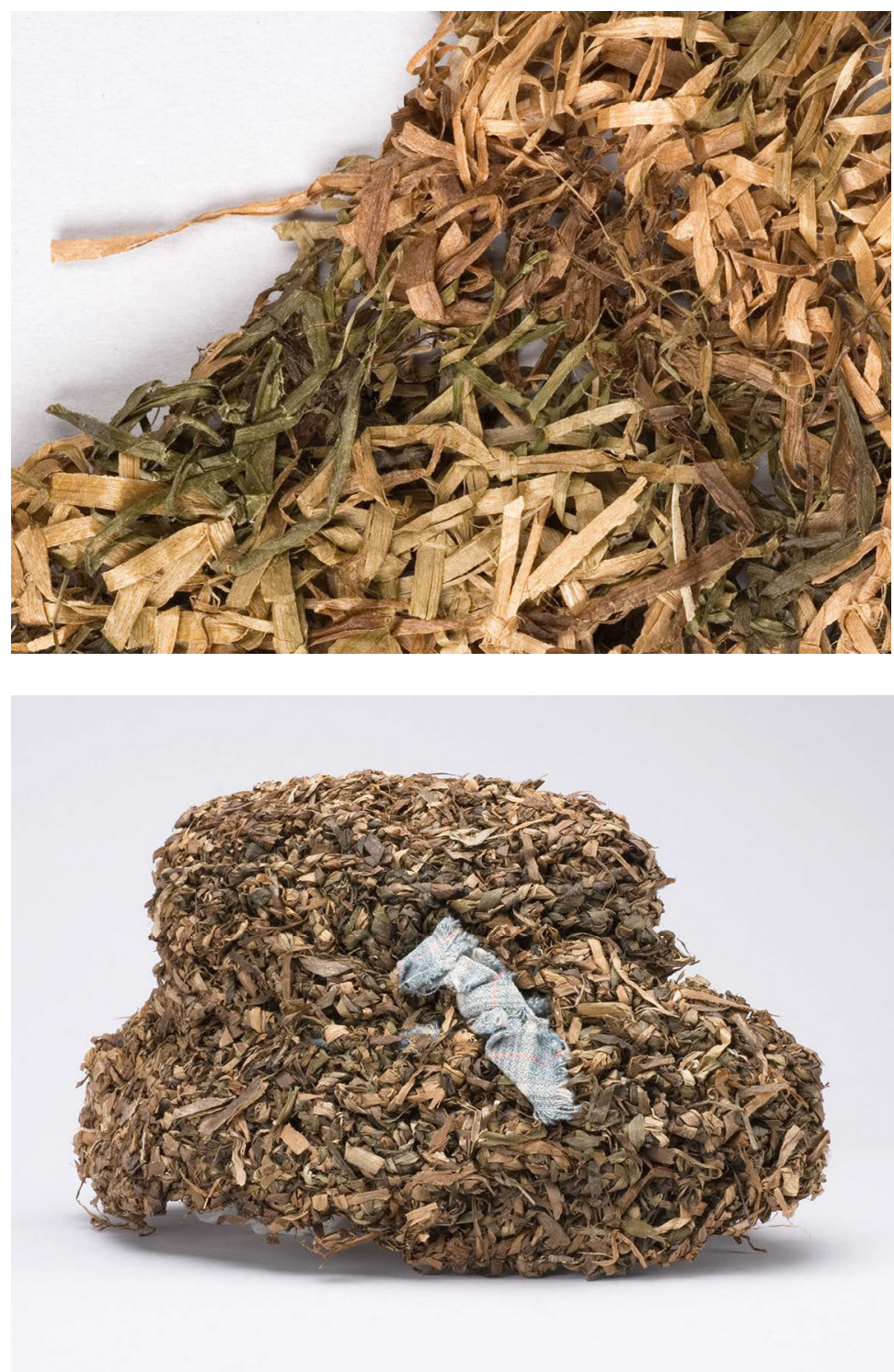

Fig. 3: Detail from left stocking with edging cotton edge (in fig. 2): stripes in various colors of split

Varek, knitted round

Fig. 4: Lisette H., women's hat, crocheted out of braided Varek, dated November 24, 1913 
the stocking into a point. Especially the slightly longer stocking with its cotton edging is extremely thin and transparent, so it becomes clear that Lisette H. intended to knit "fine" stockings, not thick wool stockings. How she was able to make the fragile texture out of stitches is inexplicable, and it is hard to imagine how Lisette H. knitted tapers or saved stitches for the heel (which forms the right angle to the foot) and transferred them to another needle (especially if one must assume that she did not have access to conventional knitting needles). She must have had extraordinary skill, experience, and a great deal of patience. The stockings are almost weightless, dry, and brittle. On September 6, 1904 the file reads: "Crochets children's dress during quiet time." She carefully crocheted such a garment, the size of a newborn's shirt, out of cotton waste and decorated the collar with a torn-off strip of brown-and-gold brocade about five millimeters wide.

In 1904 Lisette H. fell ill with pneumonia, and in 1906 she was seriously ill for several months. In that year it is noted that she "no longer makes little things" and "does not work." After 1907, the entries become sparse. For seven years there was not a single entry in her file. In 1915, I9I8, and I9I9 the only entries simply read: "Status idem," "Nothing new," and "Unchanged." After the long interruption in 1906, in 1907 Lisette $H$. began weaving ribbons out of Varek longer than the short single blades of grass, which resulted in a much more stable weave: "Endlessly wove threads out of Varek," the medical record reads. ${ }^{19}$ Despite the slightly disparaging remark about her "endless" weaving, a few years later, a hat that Lisette H. produced made a certain impression on the author of the entries. On November 24, 1913 (as was already mentioned) the file reads: "made a pretty hat out of Varek" (fig. 4). ${ }^{20}$

The new technique of braiding, crocheting, or knitting braids out of the short pieces of Varek allowed Lisette H. to make more robust and larger objects and to precisely shape them. From a technical point of view, if the hat were not so small (including the brim, it is only 26 centimeters long and 17 centimeters wide), it would be wearable. Although Lisette H. certainly did not have a hat block, her hat is exceptionally well formed. The top of it is flattened in the shape of an ellipse (one of the Varek braids runs over the top) and then bulges downward. The brim sticks outward and bulges slightly again, so that the hat, if it were worn, would somewhat shade the wearer's forehead. Both are connected with a hat ribbon, for which $\mathrm{Li}$ sette H. used a torn-off strip of a blue-and-white mattress fabric that she pulled through the Varek braids and tied in a nice bow. The loving care that Lisette $\mathrm{H}$. showed contrasts starkly with the meagre materials that were available to her. A handbag that she made in the same technique has also survived (fig. 5, 6). 


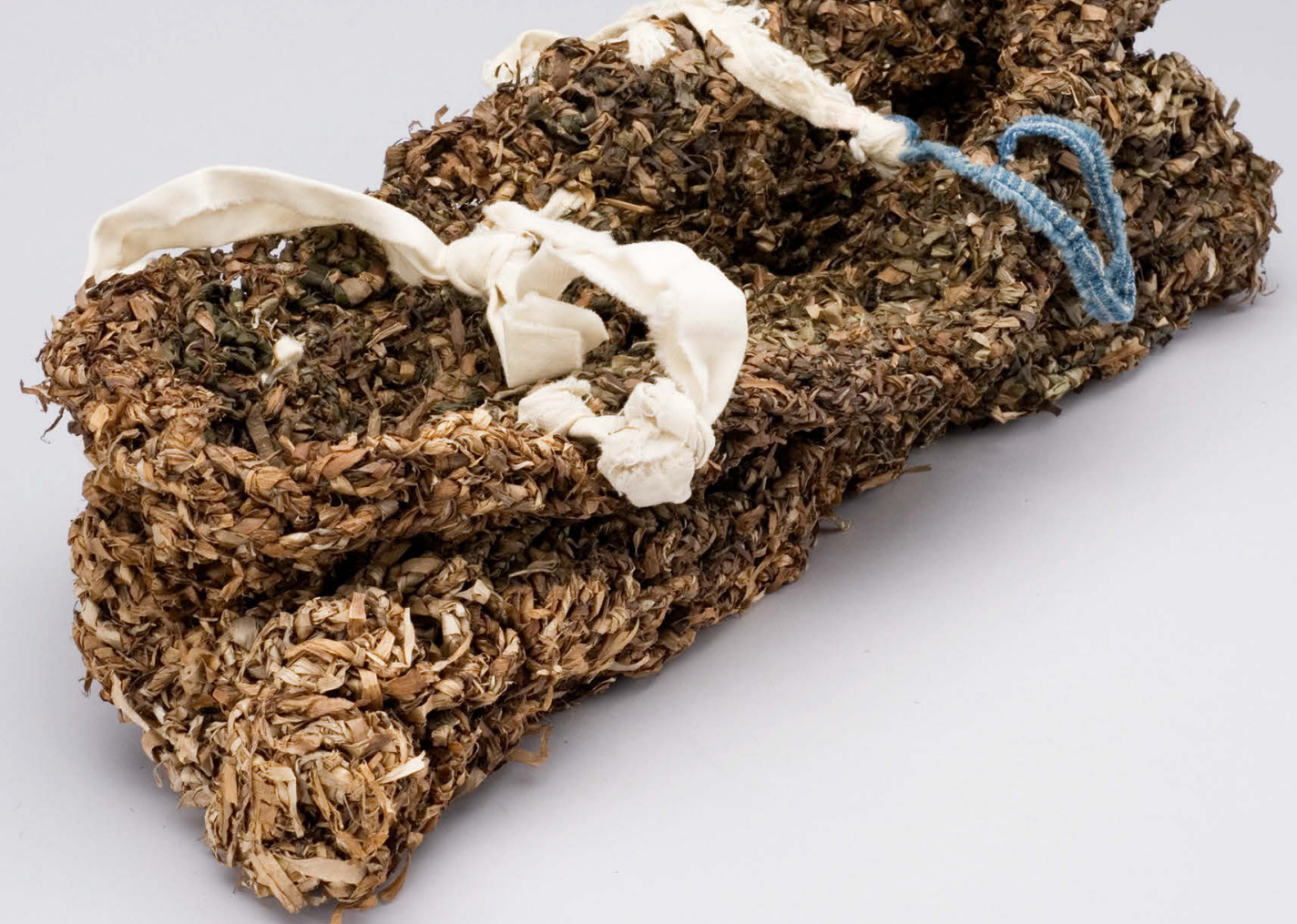

The handbag is 35 centimeters wide and $\mathrm{I} 6$ centimeters tall. The base is a five-anda-half-centimeter-wide, 35-centimeter-long rectangle, which is securely connected to the side walls. The technique in which Lisette H. made the handbag is difficult to discern, since the braids lie flat along the sides. The upper edge seems to be chained off; perhaps she used a mix of techniques here. Her self-perception was apparently different from others' perception of her, as evidenced by the Varek bracelets that she made for herself and wore. ${ }^{21}$ Although the attendants and doctors were sometimes impressed by her technical abilities their comments were largely skeptical. On the one hand, this may be due to the fact that Lisette H.'s health deteriorated from 1906 onward. Her use of the strangely inadequate material of seagrass also probably contributed to the skepticism. It was thus reminiscent of so-called "savages" and it was inscribed into the discourse of primitivism due to such associations. 
I will try to demonstrate that the attribution of the material to "primitive" qualities was one of the reasons why it was apparently impossible for Lisette H.'s psychiatrists to appreciate the unbelievable skill that Lisette $H$. showed and the grieving expressed in her choice of motifs. Her living environment, which was restricted to the observation room, the bathtub, the cell, the dayroom, and the cell yard after I893, shrank again after 1920 in her final years, and finally consisted of her bed, the space under her blanket (see also Ankele 2009b: I35-I37; 2009a: I45-I50). The only entry from I920 states: "Always has her Varek bag full of threads, stones, and the like, and plays with them." ${ }^{22}$ When she could no longer leave her bed in I924, she played with these things under the covers, tore the linens, and "makes garlands out of the pieces, puts feathers in her hair." ${ }^{23}$ In her bed and under her blanket, Lisette $\mathrm{H}$. kept a place of retreat in which the psychiatric hospital, a "total institution," in the words of the sociologist Erving Goffman, did not intervene. Goffman calls this strategy "underliving in the asylum" (Goffman I973[I96I]: 202), with which he describes actions of patients which were not allowed but were tolerated, and so were not directly subversive and made it subjectively easier for them to survive in the asylum.

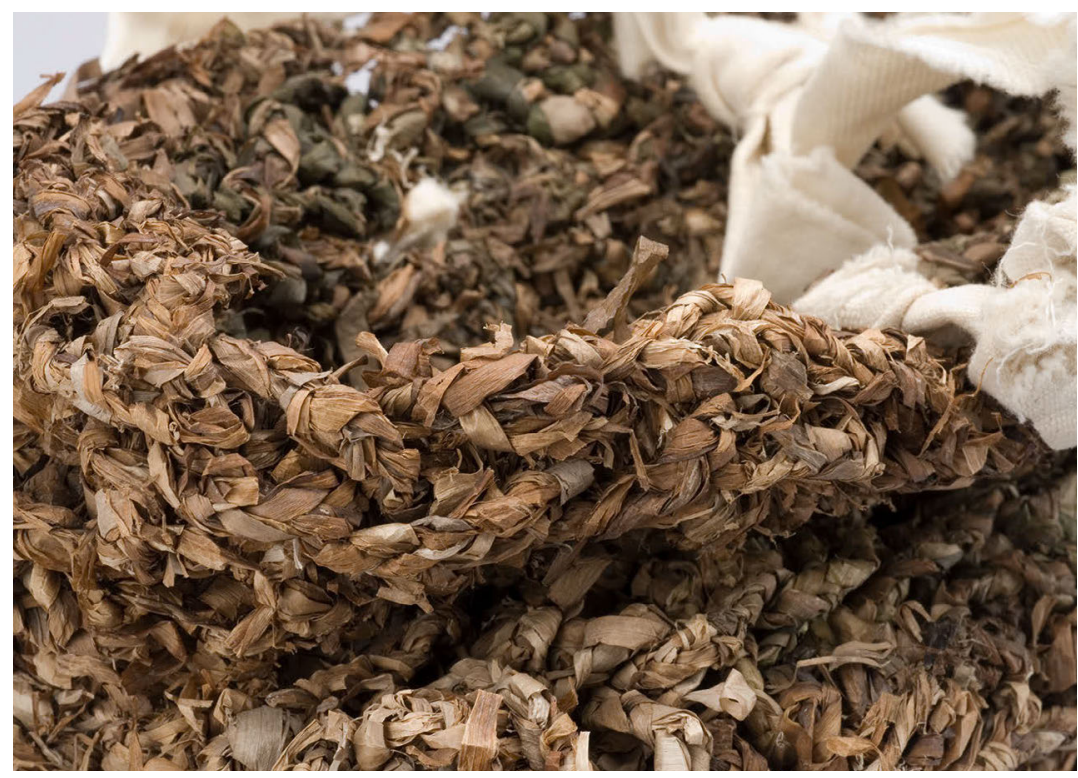




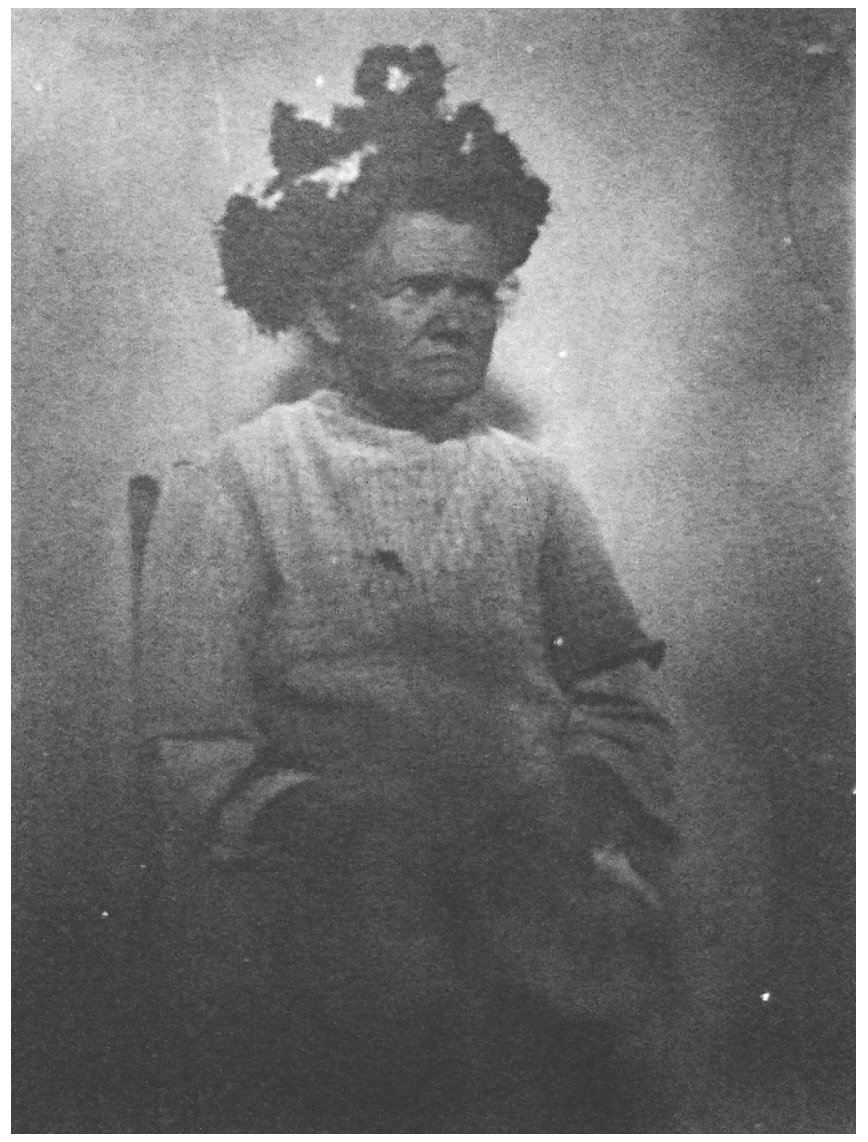

Fig. 7: Lisette H., dated 1914 


\section{"Foreign" and "Savage" Things in Photographs from the Asylum}

A photograph from I9I4 shows Lisette H. sitting on a chair dressed in a hospital gown. She is wearing a headdress made of a garland and braids, both presumably made of Varek. ${ }^{24}$ A ribbon appears to be woven into the garland and she wears bracelets of Varek (fig. 7). ${ }^{25}$

As the cultural studies scholar Susanne Regener calls it, the picture is a "photograph against the subject's will" (20I0: 95-II6, IOI). Regener uses this expression to examine the large number of photographs of patients taken between I900 and I9I4 in psychiatric institutions. Like conventional portraits, they depict an individual person in full or in close-ups. In contrast to commissioned photographs, however, the picture is not taken in agreement with and for the benefit of the subjects. There is a lack of communication, and the picture was "captured" (ibid.: 96). Photography is "the materialization of a particular medical gaze," which "attests to violence and claims to power over the individual" (ibid.). Based on the example of seven photo albums from the German Heil- und Pflegeanstalt Weilmünster, Regener examines what might also apply to Lisette H.: the fact that the photographed patients often came from lower social classes and had no experience with how to present themselves favorably in a photograph. The hospital bed or the chair on which they were photographed sitting becomes a stage on which, often also for educational purposes for prospective psychiatrists, their mental illness was supposedly presented. In the portrait the patient is completely "medicalized ... both as a social person and as a human type" (ibid.: 95). ${ }^{26}$

In the aforementioned photograph, Lisette $H$. is sitting on a wooden chair in front of a wall. She looks watchfully or even mistrustfully into the upper right corner, where perhaps an attendant is standing, and ignores the camera. She presents herself in a costume that contrasts starkly with her simple hospital apron. With the chair in front of the bare wall, the setting is more reminiscent of a police portrait than of a conventional portrait and contrasts sharply with her impressive clothing, which she surely understood as significant.

Another comparable "materialization" of a specific scientific gaze at the beginning of the 2oth century is the innumerable anthropological photographs depicting representatives of the indigenous population of colonies in clothing that was incomprehensible to European audiences, since it was unexplained. Such anthropological pictures attracted a great deal of interest from a broad audience, includ- 
ing psychiatrists. After all, in psychiatry in the first decades of the 2oth century, cultural-historical questions, prompted by psychoanalysis - especially in the milieu of the Burghölzli clinic in Zurich - played an important role. Cultural-historical statements, for instance artworks from the Middle ages, from ancient Egypt or just as well from the colonies were seen as being related to early stages of development and related to the regressions caused by the onset of mental illness. Aided by the use of the medium of photography, the older concept of the criminal anthropologist Cesare Lombroso (I835-1909) of a "step backward" to earlier stages of development was entangled with anthropological explanatory models. ${ }^{27}$ An undated glass slide in the Museum of Psychiatry in Bern, which presumably also served to train psychiatrists and is found among many images from the psychiatric institution, supports this assumption: It shows an unclothed, dark-skinned woman with scar embellishments on her stomach, whose at first glance incongruous appearance in the psychiatric context must be read as a cultural-historical reference. ${ }^{28}$ A group of photographs of tattooed patients from the same collection could serve as an indication of an interest in the importance of bodily adornments. ${ }^{29}$ The Bern psychiatrist Walter Morgenthaler (I882-I965), who was very interested in artworks created by patients, wondered in his monograph about his patient Adolf Wölfli (I864-I930), who is considered one of the outstanding Swiss artists, whether, due to his illness, the artist arrived at even "more original artistic elements" (Morgenthaler I985 [I92I]: 89-90) than some avant-garde artists. Terms such as "archaic" and "primitive," as well as "ugly" and "savage" were trendsetting for the avant-garde that defied bourgeois norms as examined by the art historian Klaus Herding using the example of Picasso's 1907 work Les Demoiselles d'Avignon (Herding I992: 4I, note 58). They also gained a new connotation - if not positive, at least worthy of interest - among psychiatrists with an interest in cultural history. Some patients seem to have embraced the field of associations around the notion of the "savage" as a space for imagination, as in the photograph of a self-assured patient from the Waldau hospital posing in animalistic savagery, dressed (or dressed up?) in a Varek sash and skirt that recalled the bast skirts that were known from photographs of traditional Polynesian clothing, and adorned with feathers (fig. 8). ${ }^{30}$

His attendant clutches the square key to the scratched wooden door to an empty room whose floor seems to be piled high with the same material, and bravely and 


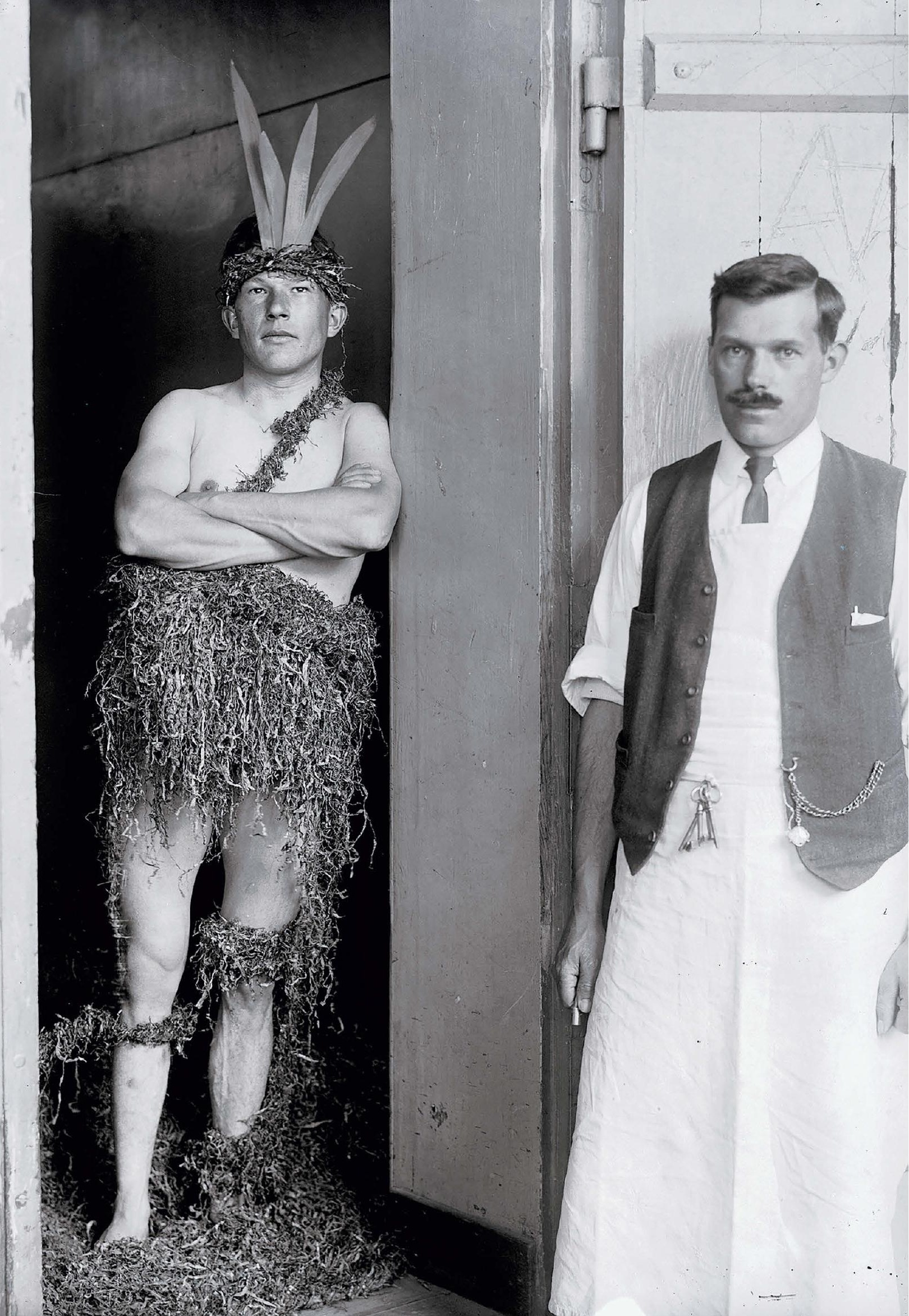


proudly presents this exotic figure, a situation reminiscent of photos of early human zoos. The material Varek, which was found in large piles after being washed, and which could be laboriously fashioned into handicrafts, though these never looked as if they had been made of spun yarn, fit into this context of the primitive and the savage.

However, Lisette H. could not benefit from this renewed interest in herself and her works for three reasons. As a woman, she was much less likely to do independent creative work than a man (Morgenthaler I9I8: 255-308); ${ }^{31}$ handicrafts were rarely considered objects of interest (Ankele 2009a: I62); ${ }^{32}$ and thirdly, Lisette $\mathrm{H}$. spent her years at the Rheinau psychiatric hospital in the wards for "half-calm" or "disturbed" women, which were described as the most hopeless places in the institution. The place where a material is found and used for creative work seems to be central to the emergence of complex works as well as their preservation and reception, which means that a doctor commented on the work and set it aside. In the following section I will discuss the importance of the ward, the place where Lisette H. spent her years in the psychiatric hospital, and the importance of the structure of the day, meaning the treatment, which consisted of making the patients work ("work therapy"), and I will examine what significance was accorded to the material Varek in this context.

\section{The Ward and Treatment}

Since its beginnings in I80o, psychiatry has divided its institutions into wards: for men and women (mostly in separate wings of the building or in their own pavilions) and for so-called calm, half-calm, and disturbed patients. Three classes of care required additional wards (Meier et al. 2007: 56-63).

Each had a yard designed according to the ward's needs: there were "cell yards" for the "disturbed" and "half-calm" wards, which were surrounded by walls or fences; residents of the calm wards had access to a garden or park and sometimes were allowed to go out on their own (Gehry 1932: 15). The division into wards was designed to prevent men and women from meeting, and agitated or aggressive patients from disturbing, threatening, or bothering calmer patients. Wards were meant to create peace and order, but they also allowed for oversight and control (Walser 1970: 4-8). ${ }^{33}$ The early psychiatric facilities built in collaboration between 
psychiatrists and architects were meant to have a therapeutic effect as carefully planned milieus. ${ }^{34}$ In Switzerland the early institutions at Préfargier (1848), Waldau (1855), Burghölzli (1870), and others were usually built in a symmetrical X or $\mathrm{U}$ shape (in some cases with annexes). For example, the calm wards of all three classes were housed in the south-facing central building of the Burghölzli clinic (Meier et al. 2007: 56). The first class was on the second floor, the second was on the third floor, and the third was on the first floor. The middle of the central building on the second floor also housed the apartment of the director and his family. The north-facing side wings with their annexes housed the "half-calm" patients, and farthest away from the director were the one-story "disturbed" wards and cell wards. The spatial arrangement of the wards shows that the bourgeois social order was reflected in this system of accommodation and in how it was handled (ibid.: 56 ). For instance, "calm" patients (those who were able to do structured and relatively complex work at the asylum) lived in brighter, sunnier, and quieter rooms than the "disturbed" patients (who, due to their condition, were unable to do 'useful' work). First-class-patients, who paid a multiple of the general rate, had the most privileged living conditions. At around 1900, institutions were often built in the pavilion style. The annexes to the Rheinau hospital had been built in I9oI, when Lisette H. arrived there, consisting of four large two-story pavilions for about Ioo people each (four wards), two for men and two for women (fig. 9).

Each ward housed around 25 people, and there were several observation rooms, a day room, and cells (Gehry I932: 20-2I). The aerial photograph from 1930 shows the house of the senior physician and his family with an office, pharmacy, and treatment room facing the Rhine. Behind it on the north side (left) are three pavilions for "calm," "half-calm," and "disturbed" women, and to the right the same arrangement for men. In I9OI II7 patients lived in the original pavilions. By 1902 there were already around 400 (ibid.: 36). In I9I4 two pavilions were built for an additional 250 patients (in the foreground of the picture), and the kitchen area was constructed (ibid.: 20). The hospital between Alt-Rheinau and Neu-Rheinau now had a total of IO77 patients, making it one of the largest in Switzerland. Like many rural asylums, Rheinau was self-sufficient, which meant that attendants, patients, and specialists had to work in the vegetable gardens and fields as well as the kitchen, laundry rooms, and tailoring workshop (Blum 2010: 23-30). It had only one class of care. Nevertheless, there was a system of privileges, which resulted in a hierarchy. ${ }^{35}$ In the "calm work wards," patients had limited freedoms and few possessions: "The 'well behaved' had all sorts of belongings with them, perhaps a picture on the wall, 
a bedside table," writes the psychiatrist Karl Gehry, senior physician of the Rheinau psychiatric hospital (1932: 22). Rewards were also given, allowances were paid, extra food was offered, and permission to come and go freely was granted for strenuous or difficult jobs. However, these were only given out in the calm wards, because in the "disturbed" wards only monotonous and simple tasks were required or permitted.

Furthermore, patients were not only assigned to the wards according to their condition, but the transfer to another ward was frequently used as a disciplinary measure and as such part of the treatment: patients were also sent to a "disturbed" ward as punishment. Insight into this practice can be gained from the autobiography of the patient Anna Z. (I867-I938), who lived at the Neu-Rheinau hospital at the same time as Lisette H. (Luchsinger 20I3 ([19I6]). The report that she had written is an impressive demonstration of how large the differences between the wards were, how narrow the freedom of self-determination was in a "disturbed" ward, and how feared these wards were among more privileged patients. They considered the women who had to live there dirty, lazy, and uncontrollable, which contradicted a bourgeois female catalog of virtues, according to which a girl had to be clean, hard-working, and strive for good manners.

\section{The Entanglement of Work and Therapy}

The Rheinau psychiatric hospital was one of the largest farms in Switzerland and so there was plenty of work to be done. Nevertheless, in I886, when the young psychiatrist Eugen Bleuler took over as director of the Rheinau psychiatric hospital at the age of 29, many patients did not work. Bleuler saw this circumstance as responsible for many patients' poor condition. He had the men in one ward split wood and sent patients along with the guards to the fields and subsequently saw great improvements in their condition (Bleuer I898a: n. pag.). He called his ideas on the productive employment of patients work therapy, which was also meant to make it possible for the severely ill to socialize better, in specific activities or for a 


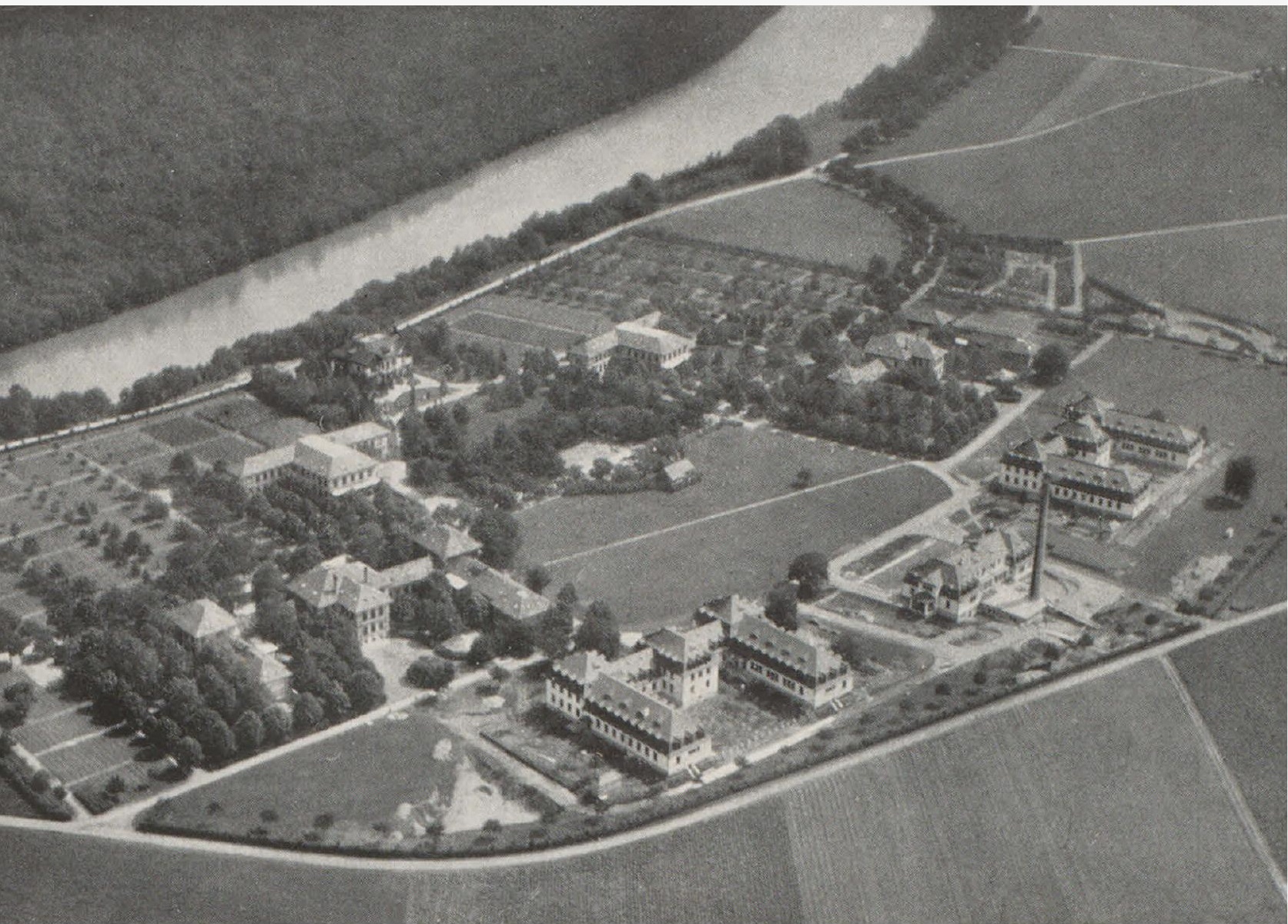

certain amount of time (Bleuer I898b). ${ }^{36}$ This could help them recover to some extent, Bleuler argued. Bleuler coined the term "social healing" (Bernet 2013: 195-206), a partial cure that was hoped to lead to a greater number of discharges. This early form of work therapy was adopted with more or less enthusiasm in almost all psychiatric institutions in Switzerland. In the Rheinau hospital there was much to do. When the first patients arrived at Neu-Rheinau in I90I, "every square meter of garden land ... had to be dug up over and over, passed through sieves, and cleared of stones.... This enormous task was just right for us, since we had all kinds of work for patients, which never ran out" (Gehry 1932: 24). For patients who could not even perform such tasks, Gehry introduced the concept of "occupation," which included both handicrafts and artworks: 


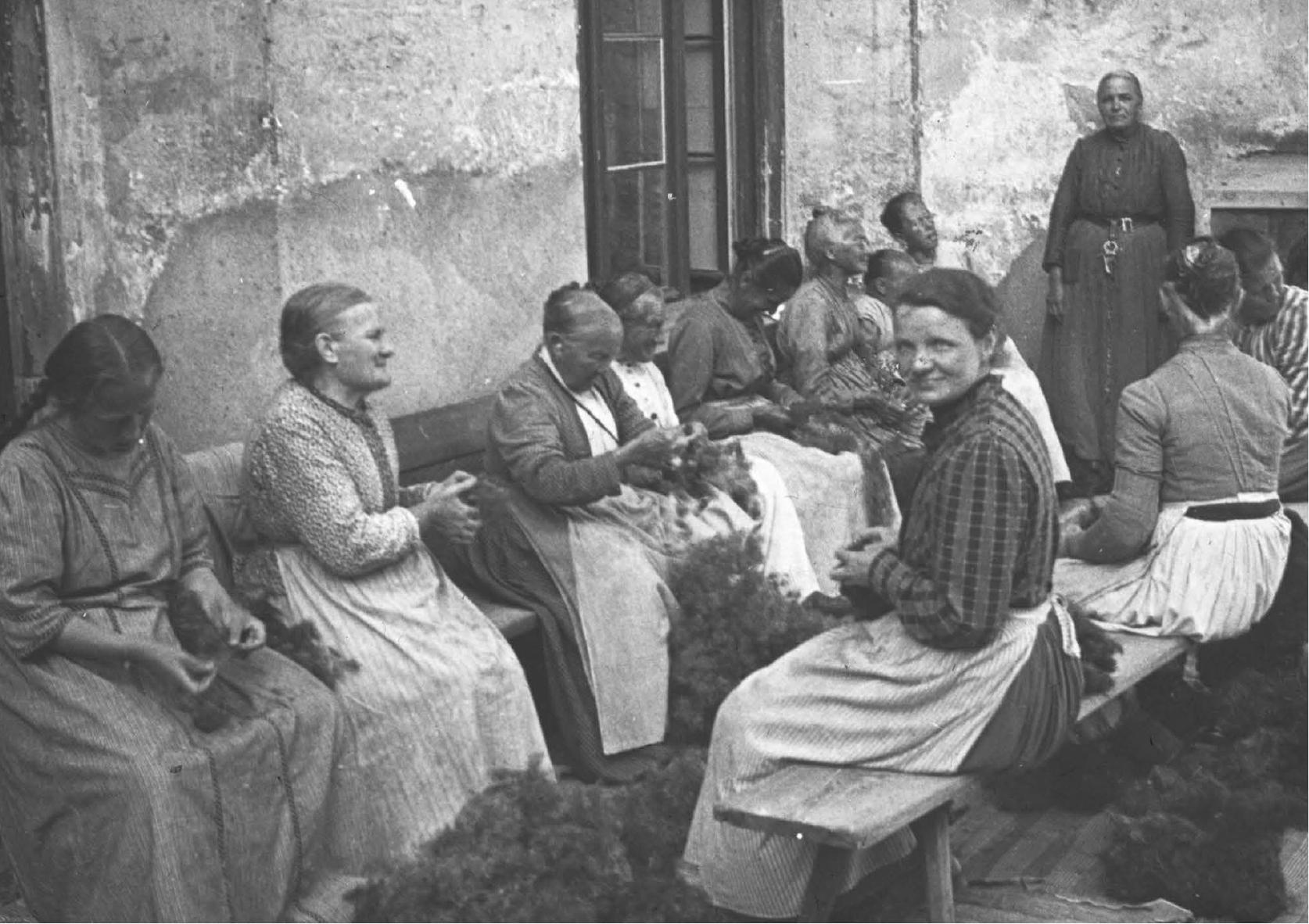

Almost all the women are given knitting or sewing tools, even if to them it is more like a toy than a tool for work; at least they believe that they are doing something, even if their successes do not go so far that we can record them on the work inspection. If a patient initially does not want to work, but draws, ... knits, ... we have nothing against that; however, one day these activities will lead to more useful work. (Ibid.: 47)

Lisette H. stayed either in the day room, in her cell, or in the courtyard surrounded by a picket fence, covered in part with gravel, where she fluffed Varek or horsehair. The material Varek, which was mainly found here, was densely "inscribed," so to speak, with the connotations and judgements on this place and these activities. 
In his popular monograph on the Rheinau psychiatric hospital, Karl Gehry includes a picture of the process of "horsehair fluffing" (which here can stand in for "Varek fluffing") in Alt-Rheinau (fig. Io).

The photo shows eleven patients, their feet sinking into bales of horsehair, which they fluff under the watch of the strict supervisor in the background with a keychain on her belt. Gehry devotes a chapter of his richly illustrated monograph to "treatment." In his commentary on the series of photographs (it shows women preparing vegetables, men weaving straw mats, four handicrafts that illustrate the concept of "occupation," and three photos of agricultural work), he says that work is not compulsory, but that patients should not be left to themselves. Even if they only believed that they were achieving something, their work should be tolerated because it could lead to the "drive to do something more useful" (ibid.: 47, image ibid., no. 3).

Figure Io shows two rows of patients. Walls and two attendants block off the narrow space on three sides. The second attendant, who sits closest to the foreground in a clean apron on the bench, looks into the camera with a friendly face and horsehair in her hands, pointing to the potential usefulness of the activity, like her older colleague. However, many of the patients are looking amusedly to the right, where something entertaining seems to be happening.

Women like these, the psychiatrist suggests based on the photograph, are the most severely impaired, still "beginners" in work therapy. At some point something useful could result from their efforts. The piles of horsehair photogenically represent the disorder against which psychiatric treatment competes in a friendly and patient manner.

Spinning Straw into Gold:

The Range of Meanings Revealed by Lisette H.'s Handicrafts

With the eight works that have survived, Lisette $H$. opens up a different range of meanings from the perspective of an art historian than that intended by the psychiatrists. Her choice of motifs was decidedly limited. Each of her objects is carefully and lovingly designed with an attention to detail. Her works require an unusual, almost unimaginable degree of craftsmanship and patience. These are skills that Lisette $H$. acquired as a housewife and not only had not lost, but perfected with the unwieldy material. The contrast to the aforementioned psychiatric attributions 
(confusion, disorder, and uselessness) could not be greater. It becomes clear from her works that the material itself does not produce any meaning, but is open to any attribution.

Although, based on the entries in her medical record, only a few of Lisette H.'s works were preserved, without exception these revolve thematically around the tasks on the one hand, and on the other hand the appearance or status of a housewife and mother. Especially the fact that she wore a handbag, hat, and fine stockings distinguished the bourgeois woman outside of her home. By limiting her motifs, Lisette H. says little about her biography or her personal experiences, and instead addresses the social role of housewives and mothers. It cannot be ruled out (a letter included in the file suggests as much) that at times Lisette H. denied that she lived as a patient in the asylum. However, this does not explain the efforts that she made to overcome the greatest technical difficulties and, over the years, to make stockings, hats, bags, jewelry, and jackets for infants out of a material that barely allows these things to be worn. However, this makes sense, because Lisette $\mathrm{H}$. left behind everything that these objects represent and no longer had any use for them. By turning to Varek as a knitting material that was actually not suitable for her purposes, she created things that represented something that meant a great deal to her, but that she had lost. The incongruity of the objects is not due to the fact that she used the "wrong" material for jewelry, garments, etcetera, but that she continued to use this material, and with the help of this incongruity evoked both her role as a housewife and mother and the loss of this role. Her skill makes her objects easily recognizable and almost usable. By continuing to do what she was used to doing at the asylum, but under living and working conditions that made the success of her work impossible, Lisette $H$. created a context of meaning. She gave her grief over the loss of her former duties a form that showed it to be continued, and thus incurable. The material speaks through the constellations that she created. She presented a difficult, even unsolvable situation to an imaginary public and answered it emotionally. A transdisciplinary notion of art which is interested in the relationship to "foreign" things, as the art historian Carl Einstein conceived as early as I9I4, or the designs for an expanded conception of art that Bauhaus artists with experience in textiles pursued could even at her time have been interested in Lisette H.'s works if they had had the opportunity to see them. ${ }^{37}$ All the more a current notion of art that is open to investigating as complex conditions as an asylum, conditions that question all attributions of authorship, of creation, and of the access to the public can focus on researching an oeuvre like hers. 


\section{Notes}

1

State Archives of the Canton of Zurich (in the following StAZH), patient file, Rheinau psychiatric hospital, Z 542, KG no. 2644, no page, entry from November 24, 1913: "Recently made a pretty hat out of Varek."

\section{2}

The eight objects made by Lisette H. are now at the State Archives of the Canton of Zurich (StAZH, inventory numbers Z 542.15 to Z 542.22).

\section{3}

These beds were sacks filled with Varek or straw without springs, or ordinary mattresses without a bedframe. Cantini and Pedroletti even mention cellfloors covered with Varek (2000: 77-79).

\section{4}

In the annual report ( Jahresbericht, in the following JB) from 1897, it was noted that a a spin-dryer for seagrass [Varektröchne] was purchased. Pflegeanstalt Rheinau, 1897 annual report, no page.

\section{5}

Cardboard boxes, chewed cardboard, envelopes, berries, grass, paper, chewed bread, marrowbones, silver paper, and other things were used for jewelry, garlands, sashes, weapons, and many other things. On a cardboard revolver from the Morgenthaler Collection (inv. no. 66) see Wernli (2018: 60-71). The Morgenthaler Collection at the Psychiatrie-Museum Bern includes a braided shoe made of Varek (inv. no. 73). Eugen Bleuler (1916) photographed a patient with a Varek sash (fig. 35) as well as a patient wearing a crown of rowan berries (fig. 42), and Angus Ma Phee (1916-1996), a patient at the Craig Dunan clinic in Scotland from 1950 to 1996, knitted clothing out of braided grass. Most of his objects are now part of the Scottish Collection of Art Extraordinary in Pittenweem, Scotland, and some are in the Collection de l'Art Brut in Lausanne, see Laing (2011: 91-102).

\section{6}

An infant jacket made of cotton waste by Lisette $H$. is also preserved (StAZH Z 542.21).

\section{7}

Entries in Lisette H.'s patient file which refer to handicrafts with Varek: March 25, 1902: "Crochets with Varek using a match." May 22, 1902: "Knits a well-proportioned stocking out of split and tied Varek using only a match." May 8 , 1904: "Asks for knitting supplies." June 13, 1906: "Hasn't created little things anymore in a long time." August 23, 1907: "Braids threads of Varek endlessly." June 22, 1907: "Makes rings out of Varek." September 22, 1911: "Often makes various things out of Varek such as hats, stockings, etc.; ties the Varek threads together, out of which she laboriously forms a mesh." November 24, 1913: "Recently made a pretty hat out of Varek." August 1, 1920: "Always has her Varek bag full of threads, stones, and the like, plays with it."

\section{8}

Since objects made of Varek are extremely fragile, there is no history of the reception of objects made of Varek outside the asylum from the time of their creation.

\section{9}

StAZH, Z 542, KG no. 2644, no page; registration by Eugen Bleuler: supplement.

\section{0}

The private foundation of Johann and Maria Hedinger was renamed the Privat-Heil- und Pflegeanstalt Kilchberg in 1888, now the Sanatorium Kilchberg, cf. https://www.sanatorium-kilchberg. ch/ueber-uns/geschichte-tradition-refugium/.

11

The "gloves" were fingerless linen gloves that were put on patients who threatened to injure themselves (Meier et al. 2007: 31)

12

StAZH, Bleuler, see note 7. "Cell clothes" were made of supposedly unrippable, rough, light gray, or striped linen fabric. 
13

Karl Gehry (1881-1962) was the physician at Rheinau. In 1908 he became senior physician, and from 1909 to 1931 he was responsible for Neu-Rheinau in this capacity. From 1931 to 1943 he was director of the Rheinau psychiatric hospital. Gehry writes that on October 23, 1901 "a number of patients from the most overcrowded wards from the old building [moved] to Neu-Rheinau. Soon others from Burghölzli followed." This must refer to the "mass transport" on October 28. Around the new buildings there was still rubble from the construction (Schoop-Russbült 1988: 11). The patient file includes both dates, October 23 and 28, 1901, StAZH, Z 542, KG 2644.

\section{4}

Construction on the annexes to the Alt-Rheinau psychiatric hospital, called Neu-Rheinau, began in 1901. They were expanded in 1907 and 1931.

They consisted of four and later six pavilions for 80 to 120 patients with wards K ("calm, capable of working"), L ("disturbed"), and M ("in need of care"). One pavilion had four wards with 25 patients each. Each had observation rooms (eight beds), a common room, and cells. "Disturbed" wards were surrounded by a wooden fence. In 1901, 117 patients lived in the new buildings. In 1907 there were 500. In 1914, 1077 patients lived at both hospitals, slightly more women than men (cf. Gehry 1932: 15-20).

15

StAZH, Z 542, KG 2644, no page, entry from November 15, 1901.

16

Ibid., entry from January 16, 1902.

17

Ibid., entry from May 22, 1902.

18

At the Rheinau psychiatric hospital, in 2001, when part of the institution was closed down, there were 825 works by patients left that had been collected, ranging from the time of the clinic's founding in 1876 into the 1960s.
This "Rheinau Collection" was inventoried in 2008 as part of a research project of the Zurich University of the Arts under the direction of the author and funded by the Swiss National Science Foundation, and is now in the State Archives of the Canton of Zurich. See Luchsinger/Blum/ Fahrni/Dessort Baur/Rufer (2018).

19

StAZH, Z 542, KG 2644, no page, entry from June 22, 1907. Entry from September 22, 1911: "Often makes various things out of Varek such as hats, stockings, etc." Ibid.: "Knots the Varek threads together, out of which she laboriously forms a mesh."

20

Since the entries in the patient files are not signed, it cannot be said who wrote the individual entries. On individual assistant physicians, see Schoop-Russbült (1988), various notes.

21

StAZH, Z 542, KG 2644, no page, entry from August 23, 1907: "Makes rings out of Varek for herself."

22

StAZH, Z 542, KG 2644, no page, entry from August 1, 1920.

23

StAZH, Z 542, KG 2644, no page, entry from August 24, 1924.

24

The photo is included in the patient file, StAZH, Z 542, KG 2644, no page.

25

StAZH, Z 542, KG 2644, no page, entry from August 23, 1907: "Makes rings out of Varek."

26

Regener quotes the sociologist Robert Castel (1979: 11).

\section{7}

Cesare Lombroso described such "regressions" in 1860 as "atavism." His hypothesis was widely accepted by psychiatrists. Lombroso saw a 
relationship between what in cultural history was assumed to be "early" and a "regression" as a result of hereditary mental illness to ontologically and even phylogenetically "earlier" stages. Lombroso (1887; 1906: 325-330), here in: Luchsinger (2016: 89-104).

\section{8}

This glass slide is the only one in this kind of ethnological photograph from Africa in a collection of 800 slides, most of which depict situations at the Swiss Waldau cantonal mental hospital. Some of the pictures are private travel photos. Psychiatrie-Museum Bern, glass slide collection, Sig. K04-098. On the collection at the Psychiatrie-Museum Bern, see Altorfer (2008).

\section{9}

Psychiatrie-Museum Bern, undated, Sig. K08-092, K05-036.

\section{0}

Psychiatrie-Museum Bern, undated, sig. K11-037.

\section{1}

"Much more significant and consistent with the findings from the children's drawings is the strong preponderance of the male sex over the female (59 men and 18 women)," writes Walter Morgenthaler in his postdoctoral thesis (1918: 257), for which he reviewed 8000 patient files from the Waldau hospital from between 1855 and 1918. See also Luchsinger (2016: 283-286).

\section{2}

In the collection of around 2600 works by patients, which he accumulated between 1918 and 1930, Morgenthaler gave all the works inventory numbers except the handicrafts. See Luchsinger/ Blum/Fahrni/Dessort Baur/Rufer (2018) as in note 20: Inventar der dreidimensionalen Objekte der Sammlung Morgenthaler, 310 objects, 183 of which are handicrafts, https://blog.zhdk.ch/ bewahrenbesondererkulturgueter/3-6-bernwaldau/. Ankele (2009a: 162-165) points to the fact that particularly in the case of pieces of clothing deviations were subject to sharp observation and strict judgement.
33

On the significance of the wards, see also Ankele (2009a: 83-86).

\section{4}

On the hospital buildings up to 1930, for instance those in western Switzerland: Fussinger/Tevaerai (1997); Luchsinger (2016: 150-155). For the Burghölzli university psychiatric clinic, see Meier et al. (2007: 56-62).

\section{5}

The privileges were modest: additional food for dinner, lemonade, a small allowance, toothpaste (cf. Luchsinger 2016: 175).

\section{6}

Beginning in 1924, the elaborated concept of work therapy ("active treatment of patients") according to Hermann Simon, director of the Heil- und Pflegeanstalt Gütersloh, became prevalent throughout Europe. Simon presented it in 1924 at the annual conference of the Deutscher Verein für Psychiatrie. It was also enthusiastically adopted in Switzerland. On the interwoven discourses around work and therapy in the interwar years, see Germann (2007: 195-233); on the concept of "social healing," see also Bernet (2013: 195-206); the most successful person to engage in theory and practice with the conditions that work as a means of therapy had to fulfill was Moritz Tramer (1927/1928, 1927: 187-213; 1928: 122-144), director of the Rosegg hospital in Solothurn. On the relationship between the concept of work therapy and artistic creation, see Luchsinger (2016: 171-180).

\section{7}

See for example Einstein (1994 [1914]: 234), preface in exhibition catalog. Here Einstein criticized the fact that "Distance and prejudices ... impede any aesthetic assessment [of African art, addition by KL], indeed prevent it altogether, because such an assessment requires proximity." His critique also concerns evolutionary hypotheses and "a false conception of primitiveness" (ibid.). On women at the Bauhaus, see Müller (2019). 


\section{Image References}

Fig. 1: City Archive Schaffhausen, Friedrich Ris estate, 91/91A/91B, || 59

Fig. 2: left $40 \times 10.5 \mathrm{~cm}$, right $34 \times 9 \mathrm{~cm}, \mathrm{StAZH}$, Collection Rheinau, inv. no. R 1443.2, Z 542.16 (left), inv. no. R 1443.3, Z 542.17 (right)

Fig. 3: Photo Zurich University of the Arts (ZHdK), FP Conservation of Special Cultural Assets I, StAZH, Collection Rheinau, inv. no. R 1443.2, Z 542.16 (left)

Fig. 4: 13×26×17 cm, StAZH, Collection Rheinau, inv. no. R 1443.1, Z 542.15

Fig. $5: 16 \times 35 \times 5.5 \mathrm{~cm}$, undated, StAZH, Collection Rheinau, inv. no. R 1443.6, Z 542.20

Fig. 6: 16×35×5.5 cm, undated, photo ZHdK, FP Conservation of Special Cultural Assets I, StAZH, Collection Rheinau, inv. no. R 1443.6, Z 542.20

Fig. 7: up to 2004 supplement to KG Z 472.1526, KG 2644, StAZH, now lost

Fig. 8: Photographer unknown, patient and attendant, undated, Museum of Psychiatry Bern, K11-037

Fig. 9: Gehry, Karl (1932): Pflegeanstalt Rheinau, Kt. Zürich, Anhang Kloster Rheinau von Hermann Fietz, Zurich: Verlag Eckhardt und Pesch, p. 21.

Fig. 10: City Archive Schaffhausen, Friedrich Ris estate, 91/91A/91B, 058, from: Gehry, Karl (1932): Pflegeanstalt Rheinau, Kt. Zürich, Anhang Kloster Rheinau von Hermann Fietz, Zurich: Verlag Eckhardt und Pesch, p. 42, bottom illustration.

The following kindly gave their permission to use the illustrations:

Fig. 1, 10: City Archive Schaffhausen,

Friedrich Ris estate

Fig. 2-7: StAZH, photo: ZHdK

Fig. 8: Museum of Psychiatry Bern

\section{Bibliography}

Altorfer, Andreas (2008): In der Anstalt: Das Leben in der Psychiatrischen Klinik anfangs 20. Jahrhundert, exhibition catalog, Psychiatrie-Museum Bern, September 22, 2007-August 23, 2008, Bern: Ed. Solo.

Ankele, Monika (2009a): Alltag und Aneignung in Psychiatrien um 190o: Selbstzeugnisse von Frauen aus der Sammlung Prinzhorn, Vienna/ Cologne/Weimar: Böhlau.

Ankele, Monika (2009b): "Das Krankenbett: Raumaneignungen von Frauen in Psychiatrien um 1900." In: Schweizerische Ärztezeitung/Bulletin des médecins suisses/Bolletino die medici svizzeri 90/49, pp. 1935-1937.

Blum, Iris (2010): "Im täglichen Gang der Anstalt": Das Praxisfeld Arbeit in der Pflegeanstalt Rheinau in den Jahren 1870-1930." In: Luchsinger, Katrin/ Blum, Iris/Fahrni, Jacqueline/Jagfeld, Monika (eds.): Rosenstrumpf und dornencknie: Werke aus der Psychiatrischen Pflegeanstalt Rheinau I867I930, Zurich: Chronos, pp. 23-30.

Bernet, Brigitta (2013): Schizophrenie. Entstehung und Entwicklung eines psychiatrischen Krankheitsbilds um I9oo, Zurich: Chronos.

Bleuler, Eugen (1898 a): Jahresbericht der Pflegeanstalt Rheinau pro I897, Rheinau, unpublished. Bleuler, Eugen (1898 b): Die allgemeine Behandlung der Geisteskrankheiten: erweiterte Antrittsvorlesung an der Universität Zürich, Zurich: Rascher. Bleuler, Eugen (1916): Lehrbuch der Psychiatrie, Berlin: Julius Springer.

Cantini, Claude/Pedroletti, Jérôme avec la collaboration de Geneviève Heller (2000): Histoires infirmières. Hôpital psychiatrique de Cery sur Lausanne, 1940-1990, Lausanne: Editions d'en bas.

Castel, Robert (1979): Die psychiatrische Ordnung: Das goldene Zeitalter des Irrenwesens, Frankfurt am Main: Suhrkamp.

Einstein, Carl (1914): "Negerplastik," preface in the exhibition catalog Neue Sezession, Sechste Ausstellung, Neue Galerie, Berlin, April-Mai 1914, here in: Haarmann, Hermann/Siebenhaar, Klaus (eds.) 
(1998): Carl Einstein, Werke, vol. 1, Berlin: Fannei \& Waltz, pp. 234-252.

Fahrni, Jacqueline (2008): "Propellerknopf und Seegrashut: Materialien und Materialbeschaffung in psychiatrischen Kliniken um 1900." In: Luchsinger, Katrin (ed.): Pläne: Werke aus psychiatrischen Kliniken in der Schweiz um I9oo, Zurich: Chronos, pp. 85-93.

Fussinger, Catherine/Tevaerai, Deodaat (1998): Lieux de folie - monuments de raison. Architecture et psychiatrie en Suisse romande, I8301930, Lausanne: Presses Polytechniques et Universitaires Romandes.

Gehry, Karl (1932): Pflegeanstalt Rheinau, Kt. Zürich. Anhang Kloster Rheinau, von Hermann Fiertz, Zurich: Eckhardt \& Pesch.

Germann, Urs (2007): "Arbeit als Medizin: Die 'aktivere Krankenbehandlung' 1930-1960." In: Meier, Marietta/Bernet, Brigitta/Dubach, Roswitha/Germann, Urs: Zwang zur Ordnung: Psychiatrie im Kanton Zürich, I870-1970, Zurich: Chronos, pp. 195-233.

Goffman, Erving (1973 [1961]): Asyle: Über die soziale Situation psychiatrischer Patienten und anderer Insassen, Frankfurt am Main: Suhrkamp. Herding, Klaus (1992): Pablo Picasso: Les Demoiselles d'Avignon: Die Herausforderung der Avantgarde, "Kunststücke" series, Frankfurt am Main: Fischer.

Meier, Marietta/Bernet, Brigitta/Dubach, Roswitha/Germann, Urs (2007): Zwang zur Ordnung: Psychiatrie im Kanton Zürich, I870-1970. Zurich: Chronos.

Laing, Joyce (2011): “Angus Ma Phee." In: Peiry, Lucienne (ed.): Fascicule de l'Art Brut 23, Lausanne: CAB, pp. 91-102.

Lombroso, Cesare (1887): Genie und Irrsinn in ihrer Beziehung zum Gesetz, zur Kritik und zur Geschichte, Leipzig: Reclam.

Lombroso, Cesare (1906), "Il mio museo." In: Archivio di psichiatria, antropologia criminale e scienze penali II, aXXXIII, no. 13, April 1, pp. 325-330.

Luchsinger, Katrin (ed.) (2013 [1916]): Anna Z., Schneiderin: "Lebensbeschreibung einer (Unglücklichen!) sowie die Schilderung der Erlebnisse wäh- rend zehn Jahren im Irrenhaus," Zurich: Chronos. Luchsinger, Katrin (2016): Die Vergessenskurve: Werke aus psychiatrischen Kliniken in der Schweiz um I9oo: Eine kulturanalytische Studie, Zurich: Chronos.

Luchsinger, Katrin/Blum, Iris/Fahrni, Jacqueline/ Dessort Baur, Isabelle/Rufer, Anita (eds.) (2018): Bewahren besonderer Kulturgüter I, https://blog. zhdk.ch/bewahrenbesondererkulturgueter, accessed August 17, 2019.

Morgenthaler, Walter (1918): "Übergänge zwischen Zeichnen und Schreiben bei Geisteskranken."

In: Schweizer Archiv für Neurologie und Psychiatrie 3/2, pp. 255-308.

Morgenthaler, Walter (1985 [1921]): Ein Geisteskranker als Künstler: Wölfli, Vienna/Berlin: Medusa.

Müller, Ulrike (2019): Bauhausfrauen: Meisterinnen in Kunst, Handwerk und Design, Munich: Elisabeth Sandmann.

Regener, Susanne (2010): Visuelle Gewalt: Menschenbilder aus der Psychiatrie des 20. Jahrhunderts, Bielefeld: Transcript.

Sanatorium Kilchberg, https://www.sanatoriumkilchberg.ch/ueber-uns/geschichte-tradition-refugium, accessed June 23, 2019

Schoop-Russbült, Birgit (1988): Psychiatrischer Alltag in der Autobiographie von Karl Gehry (I88I1962), dissertation, Zurich: Juris

Tramer, Moritz (1927/1928): "Arbeitstherapie." In: Schweizerisches Archiv für Neurologie und Psychiatrie 21 (1927), pp. 187-213, (1928), pp. 122-144. Walser, Hans (1970): Hundert Jahre Klinik Rheinau 1867-1967: Wissenschaftliche Psychiatrie und praktische Irrenpflege in der Schweiz am Beispiel einer grossen Heil- und Pflegeanstalt, published by the Schweizerische Gesellschaft für Geschichte der Medizin- und Naturwissenschaften, Aarau: Sauerländer.

Wernli, Martina (2018): "Schlüsselgeschichten: Walter Morgenthalers Sammlung nachgemachter Schlüssel." In: Luchsinger, Katrin/Hirsch, Helen/ Röske, Thomas (eds.): Extraordinaire! Unbekannte Werke aus psychiatrischen Einrichtungen in der Schweiz um 1900, exhibition catalog, Zurich: Scheidegger \& Spiess, pp. 60-71. 